\title{
MRS to Compile Database on Advanced Materials Research
}

The Materials Research Society (MRS) and Synergistic Technologies, Inc. (STI) will collaborate on a project to catalog key materials scientists, their laboratories, and their research in a one-of-itskind database. The Advanced Engineering Materials Research Profile will focus primarily on researchers in the North American university laboratory, national laboratory, and federally funded laboratory communities. It will be released in Spring 1994 and will be available in both book (directory) and computer database formats.

The project was conceived and developed by MRS in partnership with STI, Research Triangle Park, North Carolina. STI has been involved in cataloguing academic research in a variety of scientific disciplines, working with such groups as Semiconductor Research Corp., Air \& Waste Management Association, and Carolina Biotechnology Center.

The purpose of the profile is to provide an information system that will make it possible for the resources of university and national laboratories to be fully utilized. "Advances in materials and pro- cessing are vital for our country," said Tom Picraux, president of the Materials Research Society. "Through this database, we will bring together-for the first time-information on materials researchers in the key sectors of university and federal laboratories. This will enable us to assist directly in the important task of pulling the myriad materials R\&D activities into a more coherent and accessible format."

Picraux further explained that, because of limits on financial resources, and due to the fact that in most industries R\&D must focus on short-term goals, it is now particularly important that university and national laboratory resources be utilized for long-term progress.

"We also believe that the profile will have a significant impact on furthering MRS's longtime goal of improving communication and coordination between industry, academia, and government," he said. "The directory represents one positive step the Society can take in this direction. We anticipate that, as technology transfer becomes increasingly important, the profile's data will be valuable to our members, to government funding agencies, and to industrial users."

Picraux noted that MRS has always sought to address important interdisciplinary problems and to provide quality information in the area of materials, as exemplified by the MRS meetings. "The database will be a natural extension of that philosophy," he said. "Just as scientists and engineers turn to MRS meetings for new perspectives and unmatched interaction, they will now be able to turn also to the profile for a degree of detail, at the individual researcher level, available nowhere else."

Those who are materials researchers in North American universities, national laboratories, or federally funded laboratories, and who have not yet received a questionnaire form for the Advanced Engineering Materials Research Profile, should fax Synergistic Technologies, Inc. at (919) 676-0542, or send name and address to AEMRP, c/o STI, 6070-L Six Forks Road, Raleigh, NC 27609.

The deadline for receipt of completed questionnaires is December 1, 1993.

\section{Enhancing K-12 Science Education-An Update}

What's the status of the national movement to reform precollege science education? Where is it headed? What role, if any, should MRS play? And what's happening in the MRS Grass Roots Education initiative? The purpose of this article is to provide a brief response to these questions.

The current move for education reform received much of its impetus from the Governors' Education Conference in 1989, which was co-chaired by then Arkansas governor Bill Clinton. Subsequent interactions between the governors and President Bush resulted in the 1990 adoption of the following set of National Education Goals:

By the year 2000:

1. All children in America will start school ready to learn.
2. The high school graduation rate will increase to at least $90 \%$.

3. American students will leave grades 4,8 , and 12 having demonstrated competency in challenging subject matter, including English, mathematics, science, history, and geography; every school in America will ensure that all students learn to use their minds well, so that they may be prepared for responsible citizenship, further learning, and productive employment in our modern economy.

4. U.S. students will be first in the world in science and mathematics achievement.

5. Every adult American will be literate and will possess the knowledge and skills necessary to compete in a global economy and to exercise the rights and responsibilities of citizenship.
6. Every school in America will be free of drugs and violence and will offer a disciplined environment conducive to learning.

In 1991, President Bush implemented a four-part national education strategy:

1. For today's students, we must radically improve schools by making all 110,000 of them better and more accountable for results.

2. For tomorrow's students, we must invent new schools to meet the demands of a new century with a "new generation of American schools," bringing at least 535 such schools into existence by 1996 , and increasing that number to several thousand by the end of the decade.

3 . Those of us already out of school and in the workforce must keep learning if we are to live and work successfully in 